DOI https://doi.org/10.30525/978-9934-26-173-2-17

\title{
РОЛЬ НАВЧАЛЬНО-МЕТОДИЧНОГО КОМПЛЕКСУ 3 МЕДИЧНОЇ БІОЛОГІЇ У ПІДГОТОВЦІ ФАХІВЦІВ З ФІЗИЧНОЇ ТЕРАПІЇ ТА ЕРГОТЕРАПІЇ В ЗАКЛАДАХ ВИЩОЇ ОСВІТИ
}

\author{
Кравчук М. Г. \\ кандидат медичних наук, доцент, \\ доиент кафедри біології \\ Національний медичний університет імені О. О. Богомольия \\ Гурняк О. М. \\ кандидат біологічних наук, \\ старший викладач кафедри біології \\ Наиіональний медичний університет імені О. О. Богомольия \\ Романенко О. В. \\ доктор біологічних наук, професор, \\ завідувач кафедри біологіі \\ Національний медичний університет імені О. О. Богомольия \\ м. Київ, Украӥна
}

В умовах розвитку вищої медичної освіти актуальною $є$ підготовка конкурентоздатних фахівців з урахуванням упровадження інноваційних освітніх технологій в навчальний процес. Цьому сприяють його якісне навчально-методичне забезпечення, зокрема, створення навчальнометодичного комплексу з конкретної навчальної дисципліни та регулярне підвищення кваліфікації викладачів.

Навчально-методичний комплекс базується на сукупності нормативних, навчально-методичних та програмних матеріалів 3 навчальної дисципліни, $є$ вагомим інструментом для ефективного виконання робочої навчальної програми 3 дисципліни, формування в студентів відповідних компетентностей, передбачених освітньою-професійною програмою. Структура та зміст навчально-методичного комплексу визначаються формою навчання студентів, специфікою викладання навчальної дисципліни, зокрема, формою проведення занять. Розроблення навчально-методичних матеріалів, що включаються до нього, має здійснюватися на компетентнісній основі із забезпеченням принципу студентоцентрованості $[1,2,3]$.

Для викладання навчальної дисципліни «Медична біологія» студентам першого курсу Національного медичного університету імені 
О.О. Богомольця, підготовка яких відбувається на першому (бакалаврському) рівні вищої освіти в галузі знань 22 «Охорона здоров'я» за спеціальністю 227 «Фізична терапія, ерготерапія» кафедрою біології розроблено навчально-методичний комплекс згідно до вимог відповідного Стандарту вищої освіти [4].

Метою створення цього комплексу було забезпечення підвищення ефективності навчального процесу під час вивчення дисципліни «Медична біологія» майбутніми фахівцями в галузі фізичної терапії, ерготерапії. Він відповідає вимогам освітньо-професійної програми та навчального плану з дисципліни «Медична біологія», використовується для організації аудиторної роботи та позааудиторної самостійної роботи студентів, підготовки та проведення поточного і підсумкового контролів рівня засвоєння ними знань і оволодіння ними практичними навичками.

Згаданий навчально-методичний комплекс 3 навчальної дисципліни «Медична біологія» містить відповідні складові, у тому числі робочу навчальну програму, силабус, тематичні плани лекцій, практичних занять, самостійної роботи студентів, засоби контролю знань (поточного та кінцевого); комплекс рекомендованих для використання навчальних книг $[5,6,7]$, навчально-методичні матеріали до проведення лекцій (у тому числі наповнені сучасним контентом презентації), практичних занять, до самостійної роботи студентів, тестових завдань у форматі «Крок-1» та ситуаційних задач для розв'язання, матеріали для підсумкового контролю засвоєння навчальної дисципліни студентами тощо.

Створений навчально методичний комплекс 3 медичної біології відповідає сучасним науково обгрунтованим вимогам до методичного забезпечення навчального процесу у закладі вищої медичної освіти, характеризується логічною послідовністю і структурованістю його складових, спрямований на забезпечення отримання здобувачам вищої медичної освіти необхідних теоретичних знань та практичних навичок.

\section{Література:}

1. Навчально-методичне забезпечення освітніх компонентів: довідник для пед. та наук. -пед. працівників / уклад. Н.М. Савельєва. Полтава: ПНП імені В.Г. Короленка, 2017. 80 с.

2. Філоненко М.М. Методика викладання у вищій медичній школі на засадах компетентнісного підходу: Методичні рекомендації для викладачів та здобувачів наукового ступеню доктора філософії $(\mathrm{PhD})$ ВМ(Ф)НЗ України. Київ, 2016. 88 с.

3. Дубінін С.І., Пілюгін В.О., Ваценко А.В., УлановськаЦиба Н.А., Передерій Н.О., Рябушко О.Б. Навчально-методичне та матеріально-технічне забезпечення освітнього процесу при викладанні 
медичної біології. Вісник проблем біології $i$ медицини. 2018. Вип. 3. С. 220-223.

4. Наказ МОН України від 19.12.2018 № 1419 «Про затвердження стандарту вищої освіти за спеціальністю 227 «Фізична терапія, ерготерапія» для першого (бакалаврського) рівня вищої освіти» [Електронний ресурс]. - Режим доступу: https://mon.gov.ua/storage/app/ media/vishcha-osvita/zatverdzeni\%20standarty/12/21/227-fizichna-terapiyaergoterapiya-bakalavr.pdf

5. Пішак В.П., Бажора Ю.І., Брагін Ш.Б., Воробець 3.Д., Дубінін С.І., Жегунов Г.Ф., Ковальчук Л.С., Корольов В.О., Костильов О.В., Кулікова Н.А., Піскун Р.П., Романенко О.В., Слесаренко О.Г., Стеблюк М.В., Федченко С.М. Медична біологія: Підручник / за ред. В.П. Пішака, Ю.І. Бажори. Видання 3-є. Вінниця: НОВА КНИГА, 2017. 608 с.

6. Романенко О.В., Кравчук М.Г., Грінкевич В.М., Костильов О.В. Медична біологія: Посібник 3 практичних занять / за ред. О.В. Романенка. 2-е вид. Київ «Медицина», 2020. 472 с.

7. Збірник завдань для підготовки до тестового екзамену 3 природничо-наукових дисциплін «Крок-1. Загальна лікарська підготовка» / Кол. авторів; За ред. В.Ф. Москаленка, О.П. Волосовця, I.Є. Булах, О.П. Яворовського, О.В. Романенка, Л.І. Остапюк. Київ: Медицина, 2004. 368 с.

DOI https://doi.org/10.30525/978-9934-26-173-2-18

\title{
РЕЗУЛЬТАТИ АНКЕТУВАННЯ ПІЛОТІВ ЩОДО ГОТОВНОСТІ ДО МІЖКУЛЬТУРНОЇ ВЗАЕМОДІї
}

\author{
Мартиненко Н. О. \\ аспірантка кафедри професійної педагогіки \\ та сочіально-гуманітарних наук \\ Льотна академія \\ Наиіонального авіаційного університету \\ м. Кропивницький, Україна
}

Міжкультурний склад студентів льотних закладів вищої освіти висуває перед освітньою системою комплекс проблем, пов'язаних не тільки 3 багатою кількістю мов і культур, але й 3 відмінностями етносів за характером та рівнем розвитку. Таким чином, стала гостро відчуватися проблема розробки нової концепції освіти, яка б дозволила 72 